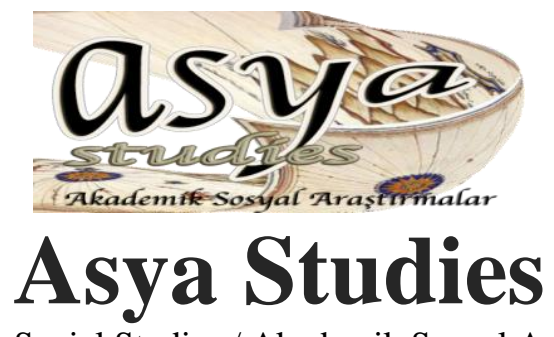

Academic Social Studies / Akademik Sosyal Araştırmalar

Year: 5 - Number: 18, p. 347-358, Winter 2021

\title{
Examining Profile of Entrepreneurs Benefit From KOSGEB New Entrepreneur Support In TRA2 Region**
}

TRA2 Bölgesinde KOSGEB Yeni Girişimci Desteğinden

Faydalanan Girişimcilerin Profilinin İncelenmesi

DOI: https://doi.org/10.31455/asya.997715

\begin{abstract}
Araştırma Makalesi /
Research Article

Makale Geliş Tarihi /

Article Arrival Date
\end{abstract}

08.09.2021

Makale Kabul Tarihi /

Article Accepted Date

29.10.2021

Makale Yayın Tarihi / Article Publication Date

31.12.2021

\section{Asya Studies}

Kutay Şenel

PhD Student / Karadeniz Technical University, Institute of Social Sciences,

Department of Finance,

kutaysenel52@hotmail.com

\section{ORCID ID}

https://orcid.org/0000-0002-6635-6275

Prof. Dr. Kurtuluş Yılmaz Genç Giresun University, Faculty of Economics and Administrative Sciences, Department of Business Administration, kyilmazgenc@gmail.com

\section{ORCID ID}

\section{https://orcid.org/0000-0001-5637-2995}

\section{* This article derived from KOSGEB SME} Expert Thesis.

* Statements of "COPE-Code of Conduct and Best Practices Guidelines for Journal Editors": No conflicts of interest were reported for this article. Ethics committee approval is not required for this article.

\section{Abstract}

Entrepreneurs have an important role in the development of countries' economies. Entrepreneurs who contribute to the increase in economic prosperity, employment and added value in the society should be supported. In addition to the support mechanisms that affect the success of enterprises, the characteristics of entrepreneurship are also important. The purpose of this study is to determine the profile of entrepreneurs who have established businesses in the TRA2 Region by benefiting from the KOSGEB New Entrepreneur Support Program. The sample of the study consists of 102 entrepreneurs benefiting from New Entrepreneur Support in the TRA2 Region. According to the findings, it was concluded that the participants were predominantly male and married individuals, their average age was 39 ( \pm 8.5 months $)$ and they had high school and below education. The male dominance of entrepreneurs in the TRA2 region is also compatible with the general entrepreneurial profile of Turkey.

The characteristics of entrepreneurs affect the performance of their businesses. In TRA2 region, it was determined that demographic characteristics such as age, gender and marital status have a low effect, personal development factors such as work experience, education and culture have a high effect on the formation of the entrepreneurial personality of individuals. While the most important advantage of being an entrepreneur for the participants is the feeling of achievement, the biggest disadvantage is the burden of responsibility. It was concluded that the most important feature to be an entrepreneur is to have an entrepreneurial spirit. In addition, it can be said that the most important obstacle to entrepreneurship in the TRA2 region is the problem of financing. Supporting entrepreneurs will contribute to the increase in the number of entrepreneurs who create added value and to reduce the employment problem.

Keywords: KOSGEB, Entrepreneur, Entrepreneurship, Entrepreneurship Profile, Entrepreneurship Support Program

\section{$\ddot{O} z$}

Girişimciler, ülke ekonomilerinin gelişimde önemli bir role sahiptir. Toplumda ekonomik refah artışına, istihdam ve katma değer yaratmaya katkı sağlayan girişimcilerin desteklenmesi gerekmektedir. Girişimlerin başarısın etkileyen destek mekanizmalarının yanında girişimciliklerin sahip oldukları özellikler de önem taşımaktadır. Bu çalışmanın amacı, TRA2 Bölgesinde KOSGEB Yeni Girişimci Destek Programı faydalanarak işletme kuran girişimcilerin profilinin belirlenmesidir. Araştırmanın örneklemini TRA2 Bölgesinde Yeni Girişimci Desteğinden faydalanan 102 girişimci oluşturmaktadır. Elde edilen bulgulara göre, katılımcıların ăğrliklı olarak erkek ve evli bireylerden oluştuğu, ortalama yaşlarının 39 ( \pm 8,5 ay) olduğu ve lise ve altı düzeyde eğitime sahip olduklart sonucuna ulaşılmıştır. TRA2 bölgesindeki girişimcilerin erkek egemen olması Türkiye'nin genel girişimci profiliyle de uyum göstermektedir.

Girișimcilerin sahip olduğu özellikler ișletmelerinin performansını etkilemektedir. TRA2 bölgesinde bireylerin girişimci kişiliğinin oluşmasında yaş, cinsiyet ve medeni durumu gibi demografik özelliklerin etkisinin düşük; iş tecrübesi, eğitim ve kültür gibi kişisel gelişsim faktörlerinin ise etkisinin yüksek olduğu tespit edilmiştir. Katılımcılar açısından girişimci olmanın en önemli avantajı başarma hissi iken en büyük dezavantajının sorumluluk yükü olduğu görülmektedir. Girişimci olabilmek için sahip olunması gereken en önemli özelliğin girișimcilik ruhuna sahip olmak olduğu sonucuna ulaşılmıștır. Ayrıca TRA2 bölgesinde girişimciliğin önündeki en önemli engelin finansman sorunu olduğu söylenebilir. Girişimcilerin desteklenmesi katma değer ortaya koyan girișimci sayısının artmasına ve istihdam sorunun azalmasina katkı sağlayacaktır.

Anahtar Kelimeler: KOSGEB, Girişimci, Girişimcilik, Girişimcilik Profili, Girişimcilik Destek Programı

\section{Citation Information/Kaynakça Bilgisi}

Şenel, K. and Genç, K. Y. (2021). Examining Profile of Entrepreneurs Benefit From KOSGEB New Entrepreneur Support In TRA2 Region. Asya Studies-Academic Social Studies / Akademik Sosyal Araştırmalar, 5(18), 347-358. 


\section{INTRODUCTION}

A Country's economy can reach an internationally competitive level by increasing the share and efficiency of entrepreneurs in the economy and increasing the added value they provide. Entrepreneurs creating employment and transforming innovative ideas into viable actions contribute to the economic growth of countries (Meyer and De Jongh, 2018: 289). With the transition from industrial society to information society, the importance of entrepreneurship policies that contribute to economic growth has increased. In this context, creating an environment that encourages entrepreneurship, reducing the costs of establishing a business and shortening the transaction times will contribute to the increase in the level of entrepreneurship (Díez-Martín et al., 2016: 1096). Therefore, it is important to reduce the control over entrepreneurs by applying the free enterprise principle more.

Entrepreneurs have an important role in ensuring economic growth, and development. Entrepreneurship is the discovery, evaluation and use of opportunities in the process of starting a business, creating, and growing. Entrepreneurship provides a competitive advantage in the rapidly changing international business environment with innovation (Maritz and Donovan, 2015: 74). Entrepreneurs have important functions that affect the development of the economy and social life (Arıkan, 2004: 68). Risk-taking, proactivity, and innovation are among the basic elements of entrepreneurship (Zhao,2005: 26). In this context, supporting entrepreneurship with an innovative idea will contribute more to the national economy (Caliendo, Fossen and Kritikos, 2014: 4). Also, entrepreneurs have different characteristics that make them entrepreneurs and distinguish them from other people (Gartner,1989: 47).

Government subsidies are a key financial component for many entrepreneurs. In addition to the scope of support programs for entrepreneurs, it is also important to analyze the efficiency of the program and its effects on entrepreneurs (Gustafsson, Tingvall and Halvarsson,2020: 440). KOSGEB plays an important role in supporting entrepreneurship and developing entrepreneurship culture in Turkey. KOSGEB provides support to entrepreneurs during their establishment years when they need financing the most, and offers different support models to businesses that are especially innovative and operating in the manufacturing sector. The aim of this study is to determine the profile of entrepreneurs who establish a business in the TRA2 Region by benefiting from the KOSGEB New Entrepreneur Support Program. In this study, primarily the concept of entrepreneurship and the importance of entrepreneurship policies in terms of national economies will be mentioned. After giving information about KOSGEB, which plays a key role in supporting entrepreneurship in Turkey, and the support model New Entrepreneur Support, the research findings in the TRA2 region will be evaluated.

\section{THE CONCEPT OF ENTREPRENEURSHIP AND THEORETICAL FRAMEWORK}

Entrepreneur reveals economic value by taking risks in a competitive environment and making his business profitable. Also plays an important role in the development of the economy and creating employment (Muftüoğlu ve Durukan, 2004: 190). The French economist Richard Cantillon, who focused on the economic role of the entrepreneur, introduced the concept of entrepreneurship to the literature. According to Cantillon; entrepreneurs must bear the risk of selling at uncertain prices. Jean Baptiste Say has expanded this definition to include the concept of bringing together the factors of production. Thus, the entrepreneur has become the main actor of economic activity in general (Stevenson and Jarillo,1990: 18). The use of entrepreneurship in its current meaning originates from Joseph Schumpeter. Schumpeter sees the entrepreneur as agent of change with innovative ideas. He also suggested that entrepreneurship occurs under five conditions of innovation: new products, new production methods, new markets, new sources of raw materials, or new organizations (Toma, Grigore and Marinescu, 2014: 438). Due to the lack of a common definition, Neo-classicals have adopted the role of the entrepreneur who brings the markets to equilibrium, while the Austrian tradition emphasizes the importance of vigilance and competition for profit opportunities. Schumpeter, on the other hand, sees the entrepreneur as innovative in economic life (Wennekers and Thurnik, 1999: 34).

Research in the field of entrepreneurship can be categorized into four approaches: The first approach is the economic approach, which bases new job creation on economic issues and focuses on economic rationality. The second approach is the psychological approach, which argues that individual factors or psychological characteristics determine entrepreneurial activity. The third approach is the organizational-based approach, which focuses on the resources and capabilities of the new firm as the main determinant of the entrepreneurial process. The fourth approach is the sociological approach, which 
argues that the socio-cultural environment determines an individual's decision to establish a business (Alverez, Urbano and Amaros, 2014: 446).

The first step in the idea of starting a new business is to see the gaps in the market and to consider how these gaps can be closed (Ürper, 2013: 11). In this process, entrepreneurs decide on new business ideas depending on factors such as alternative career expectations, family, friends, role of exemplary models, economic conditions, available resources. In this context, the entrepreneurial process model consists of individual, sociological, and environmental factors that affect new initiatives (Bygrave, 2003: 3). Entrepreneur typologies, on the other hand, provide a basis for understanding the values, operating and thinking systems, and visions of entrepreneurs. However, the fact that entrepreneurs have different characteristics makes it difficult to create a common profile for them (Filion, 1998: 3).

A person who wants to be successful in his enterprise must have certain tendencies and personal characteristics. Because the entrepreneur's performance is determined by his abilities, knowledge and skills (Kozubíková, Dvorský, Cepel and Balcerzak, 2017: 222). The personal characteristics that entrepreneurs should have are based on the idea that they have some different internal characteristics, values and attitudes (Nishantha, 2009: 73). Studies on the characteristics of entrepreneurial personalities focus on the need for success, locus of control, risk-taking tendency, problem-solving, desire to prove oneself, tolerance for uncertainty and emotional stability (Raab, Stedham and Neuner, 2005: 73). Demographic factors such as education, age, gender, marital status, background, the social and human capital of the entrepreneur also affect their success (Man, Lau and Snape, 2008: 257-258).In addition to the psychological and behavioral characteristics of the entrepreneur, managerial skills and technical knowledge are among the factors that affect their performance (Man, Lau and Chan, 2002: 125).

\section{SUPPORTING ENTREPRENEURSHIP}

Entrepreneurs play an important role in economic development through employment, innovation, and welfare effects (Acz and Szerb, 2010: 4-5). Entrepreneurs, which are very important for a dynamic economy, affect productivity and competition by bringing new products, methods and production processes to the market with their activities (Krikitos, 2014: 1). In addition to being responsible for a large share of technological innovation in products and production processes, entrepreneurs drive economic transformation and international trade (Spulber,2008: 2). International organizations also see entrepreneurs as a key element to end poverty and social inequality, promote women's empowerment, and implement business solutions to the world's problems in climate change (GEM, 2020: 13).

The competencies that entrepreneurs in developing economies need to keep their businesses afloat and grow differ from those in developed economies (Solesvik, 2012: 1). Because the environment that shapes the economy in a country depends on access to capital and other resources, perceptions of entrepreneurs, economic development, and the interrelationship between institutions. For this reason, there are significant differences between countries in the orientation to entrepreneurial activities (Acs, Desai and Hessels, 2008: 219). Encouraging entrepreneurship is a key policy objective for states that expect high rates of entrepreneurial activity to create sustainable jobs (United Nations, Department of Economic and Social Affairs, Statistics Division, 2018: 6).

Lundstrom and Stevenson (2001) defined entrepreneurship policy as measures aimed at directly affecting the vitality level of entrepreneurship in a country or region (Audretsch,2004: 1). In the field of entrepreneurship policy, government interventions occur when market mechanisms do not sufficiently support the new firm formation and related areas such as job creation (Autio,2016: 13). In this context, states have the potential to affect the rate of new venture creation directly or indirectly with the entrepreneurship policies they follow. However, the challenge here is to create a culture that will encourage entrepreneurial activity in society (Hirsch, Langan-Fox and Grant, 2007: 586).

Most of the entrepreneurs give up their entrepreneurial activities due to the anticipated administrative burdens related to the establishment and operation of a company (Ortega-Argile's and Voigt,2009: 10). Among the main policy tools and measures for the development of entrepreneurship are removing administrative and regulatory elements for the establishment and growth of new companies, improving access to finance and information and developing other support infrastructure and services, promoting an entrepreneurial culture, integrating entrepreneurship into the education system (Dahlstrand and Stevenson, 2010: 6). With the increasing difficulties arising from globalization and the transition to a knowledge-based economy, many countries have started to attach more importance to innovation in their entrepreneurship policies (Mittelstädt and Cerri, 2008: 16). Various supports are given to entrepreneurs 
by different institutions and organizations in Turkey. Small and Medium Enterprises Development Support Administration (KOSGEB) plays a key role in supporting entrepreneurship in Turkey with the different support models it offers to entrepreneurs.

\section{SMALL AND MEDIUM ENTERPRISES DEVELOPMENT SUPPORT ADMINISTRATION (KOSGEB)}

KOSGEB, which was established in 1990 with the law numbered 3624, is a public institution with a legal personality and special budget of the Ministry of Industry and Technology (KOSGEB, 2019a: 8). The mission of KOSGEB has been determined "to increase their share in economic and social development by enabling SMEs and entrepreneurs to reach an innovative, technological and competitive structure with effective support and services" (KOSGEB, 2019b: 1). Small and medium-sized enterprises within the target audience of KOSGEB; It is defined as economic units or enterprises classified as microenterprises, small enterprises,and medium-sized enterprises, which employ less than two hundred and fifty people annually and whose annual net sales revenue or financial balance sheet does not exceed one hundred and twenty-five million Turkish Liras. (Küçük ve Orta Büyüklükteki İşletmelerin Tanımı, Nitelikleri ve Sınıflandırılması Hakkında Yönetmelik, 2005: Madde 4). As of 2020, KOSGEB provides support and services to SMEs with 88 KOSGEB Directorates in 81 provinces. In addition, 104 Representative Offices operate by KOSGEB to carry out information and guidance activities (KOSGEB, 2021a: 5).

Various support models are offered by KOSGEB to enable SMEs and entrepreneurs to be active in the ecosystem and to increase their competitiveness in the international market. For some support models, there is a requirement to prepare a project, while some do not have a project requirement. Within the scope of these support models, refundable and non-refundable supports are provided (Sevinç and Eren, 2019: 410). The ratio of the realization amount of refundable, non-refundable, and loan interest support programs within the total expenditure made in KOSGEB budget in 2019 is $84 \%$. Of this amount spent in 2019, 56.2\% are non-refundable supports, $19.4 \%$ are loan interest supports, and $8.4 \%$ are refundable supports (KOSGEB, 2020a: 35). In 2020, the rate of realization of refundable, non-refundable, and loan interest support programs in total expenditure is $79.7 \%$. Of this amount spent in 2020,64\% are non-refundable supports, $8.3 \%$ loan interest supports, 7.4\% refundable supports (KOSGEB, 2021a: 34).

Within the scope of KOSGEB Entrepreneurship Support Program, which entered into force in July 2010, it is aimed to support and expand entrepreneurship, which is the main factor in the solution of economic development and employment problems, and to establish successful businesses (KOSGEB, 2019c). Application results of KOSGEB Entrepreneurship Support Program by years are given in Table 1.

Table 1: Support Results of KOSGEB Entrepreneurship Support Program

\begin{tabular}{|c|r|r|}
\hline Years & Support Amount (TL) & Number of Supported Businesses \\
\hline 2010 & 358.291 & 69 \\
\hline 2011 & 26.252 .955 & 2.416 \\
\hline 2012 & 52.182 .573 & 4.984 \\
\hline 2013 & 85.618 .415 & 8.077 \\
\hline 2014 & 107.409 .093 & 10.207 \\
\hline 2015 & 126.665 .386 & 11.828 \\
\hline 2016 & 240.655 .517 & 15.540 \\
\hline 2017 & 443.419 .627 & 22.895 \\
\hline 2018 & 596.332 .602 & 31.790 \\
\hline 2019 & 475.289 .402 & 25.077 \\
\hline
\end{tabular}

Source: Compiled from the Activity Reports available at www.kosgeb.gov.tr.

Legislative changes made in 2015-2016 led to an increase in the amount of support paid to entrepreneurs by KOSGEB. The support process for entrepreneurs who set up their businesses by benefiting from the Entrepreneurship Support Program continues whose application for the program was closed on 31.12.2018. The support types given to entrepreneurs through the New Entrepreneur Support are shown in Table 2. After 2019, the support given to entrepreneurs by KOSGEB continues within the scope of Traditional Entrepreneur and Advanced Entrepreneur Support Program. 
Table 2: KOSGEB New Entrepreneur Support Types

\begin{tabular}{|c|c|c|c|}
\hline Support Types & & $\begin{array}{l}\text { Support } \\
\text { Upper } \\
\text { Limit (TL) }\end{array}$ & Support Rate (\%) \\
\hline $\begin{array}{l}\text { Business Establishment } \\
\text { Support }\end{array}$ & \multirow{3}{*}{$\begin{array}{l}\text { Non- } \\
\text { Refundable } \\
\text { (Grant) }\end{array}$} & 2.000 & \multirow{4}{*}{$\begin{array}{l}\text { 1st and 2nd Region } 60 \% \\
\text { 3rd, } 4 \text { th, 5th and 6th Regions } 70 \% \\
20 \% \text { is added to the support rate if the } \\
\text { entrepreneur is a woman, a veteran, a } \\
\text { first degree relative of a martyr and a } \\
\text { disabled person. }\end{array}$} \\
\hline $\begin{array}{l}\text { Establishment Period } \\
\text { Machinery, Equipment, } \\
\text { Office Hardware and } \\
\text { Software Support }\end{array}$ & & 18.000 & \\
\hline Operating Expenses Support & & 30.000 & \\
\hline Fixed Investment Support & Refundable & 100.000 & \\
\hline
\end{tabular}

Source: https://www.kosgeb.gov.tr/site/tr/genel/destekdetay/1231/girisimcilik-destek-programi

Within the scope of KOSGEB New Entrepreneur Support, 150,000 TL of support is provided, including 50.000 TL non-refundable and 100,000 TL refundable. The amount of support given to the target audience within the scope of the Entrepreneurship Support Program since the effective date of the program constitutes $39 \%$ of the total amount of support given by KOSGEB. In this context, 1.7 million TL support was given to 66,148 entrepreneurs within the scope of KOSGEB New Entrepreneur Support. 537,834 different employees were employed in the enterprises that received support. In addition, Entrepreneurship Training, which is a prerequisite for benefiting from the support program, was given to 1.2 million people (KOSGEB, 2020b).

\section{METHOD}

The TRA2 Level 2 region is located in the Northeast of Turkey and consists of four provinces, namely Ağr1, Ardahan, Iğdır and Kars. TRA2 Region, which constitutes 3.8\% of Turkey's surface area, has borders with four countries: Armenia in the east, Iran and Nakhchivan in the southeast, and Georgia in the north (Serhat Development Agency,2013: 6). The aim of this study is to determine the profile of entrepreneurs who establish a business in the TRA2 Region by benefiting from the KOSGEB New Entrepreneur Support Program. As a result of the analysis of the data obtained from the research, the level of entrepreneurship in the TRA2 Region will be evaluated and it will contribute to the creation of a data source for the region. The research covers only the TRA2 Region and the businesses established with KOSGEB New Entrepreneur Support in this region. Therefore, other businesses in the TRA2 Region were not included in the scope of the study. The data of the research is limited to the data in the KOSGEB system on April 15, 2015, when the research was conducted.

The universe of the research consists of enterprises located in Ağrı, Iğdır, Kars and Ardahan (TRA2) provinces, and the sample group consists of 102 enterprises selected by purposeful sampling method from companies established with KOSGEB New Entrepreneur Support. Purposeful sampling; "For the purposes of research, it is purposefully to take one or more subsections of a universe as a sample, rather than a representative sample. In other words, purposive sampling means making the most appropriate part of the universe the subject of observation" (Sencer,1989: 386). In this context, considering the data on April 15, 2015; A total of 261 enterprises, 120 in the province of Ağr1, 56 in the province of Kars, 45 in the province of Ardahan, and 40 in the province of Iğdır, which form the TRA2 region, were established with KOSGEB New Entrepreneur Support. The sample size of the study is 102, which means that the findings will have a 95\% confidence level and $8 \%$ margin of error (tr.surveymonkey.com).

A survey form was used as a data collection tool in the research study to be carried out in companies established with KOSGEB New Entrepreneur Support in the TRA2 Region. In the preparation of the research questionnaire, literature review method was used and previous studies on entrepreneurship were taken into account. The data collection process within the scope of the survey was carried out between February 15 and April 15, 2015. It is assumed that the entrepreneurs participating in the survey gave correct and sincere answers to the questions in the survey. The data obtained from the research were 
analyzed with the help of SPSS 20.0 statistics package program. Descriptive statistical analyzes (frequency and distribution) were used in the analysis of the data, and entrepreneurship profiles were evaluated according to the arithmetic mean and standard deviations using the literature.

Table 3:Demographic Characteristics of the Participants

\begin{tabular}{llll}
\hline Demographic Variables & Level & $\begin{array}{c}\text { Frequency } \\
\text { (n) }\end{array}$ & $\begin{array}{c}\text { Percentage } \\
(\mathbf{\%})\end{array}$ \\
\hline \multirow{2}{*}{ Gender } & Female & 38 & 37,3 \\
& Male & 64 & 62,7 \\
\hline \multirow{5}{*}{ Age groups } & $0-20$ & 2 & 2,0 \\
& $21-30$ & 32 & 31,3 \\
& $31-40$ & 43 & 42,2 \\
& $41-50$ & 25 & 24,5 \\
& $51+$ & - & - \\
& & & 72,5 \\
Marital status & Married & 74 & 27,5 \\
& Single & 28 & 20,6 \\
& & & 50,0 \\
& Primary & 21 & 9,8 \\
& Secondary Education & 51 & 17,6 \\
& Associate degree & 10 & 2,0 \\
\hline \multirow{2}{*}{ Education level } & University & 18 & $\mathbf{1 0 0 , 0}$ \\
\hline
\end{tabular}

When the distribution of the participants according to their gender is examined, it is observed that $37.3 \%$ of the participants are female and $62.7 \%$ are male entrepreneurs. When the distribution by age groups is examined, it is seen that 73.5\% of the participants are entrepreneurs between the ages of 21-40. $80.4 \%$ of the participants in the research have a lower level of university. According to marital status, $72.5 \%$ of the participants are married. In this context, according to the demographic characteristics of the sample group of the research; It can be said that the education level is low, middle-aged $(39 \pm 8.5$ months), married and predominantly male.

Table 4: Other Characteristics of the Participants

\begin{tabular}{|c|c|c|c|}
\hline Other Variables & Level & $\begin{array}{l}\text { Frequency } \\
\text { (n) }\end{array}$ & $\begin{array}{l}\text { Percentage } \\
(\%)\end{array}$ \\
\hline \multirow{4}{*}{ Province } & Ağr1 & 46 & 45,1 \\
\hline & Iğdır & 17 & 16,7 \\
\hline & Kars & 18 & 17,6 \\
\hline & Ardahan & 21 & 20,6 \\
\hline \multirow{4}{*}{ Legal status of the business } & Sole proprietorship & 99 & 97,0 \\
\hline & Limited company & 3 & 3,0 \\
\hline & Incorporated company & - & - \\
\hline & Other & - & - \\
\hline \multirow{4}{*}{ Number of employees } & 1 & 84 & 82,4 \\
\hline & $2-5$ & 15 & 14,7 \\
\hline & $6-10$ & 3 & 2,9 \\
\hline & $11+$ & - & - \\
\hline
\end{tabular}


TRA2 Region

\begin{tabular}{llrr}
\hline & Manufacturing & 29 & 28,4 \\
& Construction & 2 & 2,0 \\
& Wholesale and retail trade & 22 & 21,6 \\
& Accommodation and food activities & 12 & 11,8 \\
Field of activity & Professional, scientific and technical activities & 9 & 8,8 \\
& Other service activities & 11 & 10,8 \\
& Other & 17 & 16,6 \\
& & & \\
& & 19 & 18,6 \\
ForeignLanguage Knowledge & I know & 45 & 44,1 \\
& I knowt know little knowledge & 38 & 37,3 \\
& & & \\
\hline \multirow{3}{*}{ Computer Usage Level } & Beginning & 22 & 21,6 \\
& Intermediate & 65 & 63,7 \\
& Advanced & 15 & 14,7 \\
\hline \multirow{2}{*}{ Have you been abroad? } & Yes & & \\
\hline Total & & 68 & 66,7 \\
\hline
\end{tabular}

The distribution of the 261 enterprises that constitute the universe of the research according to the provinces and the distribution of the 102 enterprises that constitute the sample group of the research are distributed proportionally to each other. $97 \%$ of the companies participating in the research were established as sole proprietorships. It is seen that the fields of activity of the participants are manufacturing with $28.4 \%$ and wholesale and retail trade with $21.6 \%$. $82.4 \%$ of the participants benefiting from the entrepreneurship support model in the TRA2 Region generally employs 1 person because have high social security insurance premiums and low income, etc. $66.7 \%$ of the participants stated that they have never been abroad. It can be said that the foreign language knowledge of the participants and computer usage level is intermediate.

Table 5: Findings on Entrepreneurship Profiles (1)

\begin{tabular}{lrr}
\hline \multicolumn{1}{c}{ Questions } & $\begin{array}{c}\text { Frequency } \\
(\mathbf{n})\end{array}$ & $\begin{array}{l}\text { Percent } \\
(\boldsymbol{\%})\end{array}$ \\
\hline What is the most important reason for you to become an entrepreneur? & & \\
a) Economic independence & 18 & 17,6 \\
b) Family needs & 15 & 14,7 \\
c) Being your own boss & 40 & 39,2 \\
d) Doing profession & 29 & 28,4 \\
\hline
\end{tabular}

What is the source of your capital before establish a business?

b) Borrowing from relatives and friends

13,7

c) Bank loan

d) Other

What do you think is the most important step in the business start-up process?

a) Evaluation of opportunities

b) Evaluation of the business plan

c) Determination of necessary resources

d) Managing the emerging new business 14,7

What is your vision?

a) Increasing the market share

b) Making new investments

c) To protect the current structure of the company by not taking risks 


$$
\text { as? }
$$

\begin{tabular}{lr} 
a) Opportunistic & 24 \\
b) Artisan & 23,5 \\
c) Tactics & 44,1 \\
d) Modern & 20,6 \\
e) Traditional & 10,8 \\
\hline
\end{tabular}

What is the most important obstacle you faced in your process of becoming an entrepreneur?
a) Capital and financing
$76 \quad 74,5$
b) Bureaucratic obstacles
c) Lack of self-confidence

$2 \quad 2,0$
d) Lack of information
$2 \quad 2,0$
e) Insufficient market research and feasibility studies
1
f) Economic instability

98,8

Do you think it is a disadvantage for you to doing your entrepreneurial activities in the TRA2 region?

a) Yes

b) No

$48 \quad 47,1$

The most important factors affecting the entrepreneurship of the participants are " being your own boss " with $39.2 \%$ and " doing profession " with $28.4 \%$. $62.7 \%$ of the participants stated that the source of their capital to open a business is personal and family savings, $57.8 \%$ stated that the most important stage in the entrepreneurship and business establishment process is seeing and evaluating opportunities. According to the findings, it is possible to say that participants will not avoid starting their own businesses if given the opportunity in the TRA2 region, so participants have an entrepreneurial spirit.

Increasing the market share $(38.2 \%)$ and making new investments $(35.3 \%)$ are among the priority targets of the entrepreneurs. Maintaining its current structure by not taking risks $(11.8 \%)$ is seen as the least preferred target. It is possible to say that the entrepreneurs participating in the research do not hesitate to take risks in order to grow and increase their market share. $44.1 \%$ of the participants in the research consider themselves as artisan entrepreneurs with limited financial resources and experience in labor. $23.5 \%$ of the participants consider them as opportunistic entrepreneurs who have management experience and can see opportunities. While the rate of tactical entrepreneurs who use innovations and different systems in their business is $20.6 \%$, the rate of modern entrepreneurs who use modern information and communication technologies is $10.8 \%$. Traditional entrepreneurs, in other words, the rate of entrepreneurs who do not use modern information and communication technologies is only $1 \%$. According to the findings, it can be said that a significant part of the entrepreneurs in the TRA2 region who can seize opportunities, have labor experience, are open to innovations and use all kinds of information and communication technologies in their businesses, despite their limited financial resources.

Almost three-quarters of the participants $(74.5 \%)$ stated that the most important obstacle they encountered in the process of becoming an entrepreneur is the lack of capital and financial resources. Bureaucratic obstacles $(11.7 \%)$ and economic instability $(8.8 \%)$ are considered as other important obstacles in the entrepreneurship process. According to the findings, it can be said that the most important obstacle to entrepreneurship in the TRA2 region is the financing problem. If the financing problem is overcome, it can be said that people are willing to become entrepreneurs. Entrepreneurship in the TRA2 region is very limited and small in scale. It is seen that $52.9 \%$ of the participants have a view that being an entrepreneur in the TRA 2 region is a disadvantage. In addition, it is possible to say that entrepreneurs avoid taking risks because being an entrepreneur in this region is disadvantageous. 
Table 6: Findings on Entrepreneurship Profiles (2)

\begin{tabular}{|c|c|c|c|}
\hline Factors & $\begin{array}{c}\text { Mean } \\
(\overline{\bar{X}})\end{array}$ & $\begin{array}{l}\text { Standard } \\
\text { Error }\end{array}$ & $\begin{array}{l}\text { Standard } \\
\text { Deviation }\end{array}$ \\
\hline $\begin{array}{l}\text { Advantages of Entrepreneurship } \\
\text { Sense of achievement } \\
\text { Financial control } \\
\text { Respect } \\
\text { Autonomy } \\
\text { Self-improvement } \\
\text { Social benefit }\end{array}$ & $\begin{array}{l}4,7451 \\
4,1275 \\
3,4510 \\
3,2451 \\
2,8039 \\
2,6863\end{array}$ & $\begin{array}{l}, 15928 \\
, 14592 \\
, 13625 \\
, 16687 \\
, 13221 \\
, 17897\end{array}$ & $\begin{array}{l}1,60868 \\
1,47367 \\
1,37609 \\
1,68533 \\
1,33527 \\
1,80747\end{array}$ \\
\hline $\begin{array}{l}\text { Disadvantages of Entrepreneurship } \\
\text { Burden of responsibility } \\
\text { Income irregularity } \\
\text { Financing 1ssue } \\
\text { Take risks } \\
\text { Personal sacrifices } \\
\text { Time issue } \\
\text { Tolerating damage too much } \\
\text { The problem of not creating demand } \\
\text { Administrative and bureaucratic affairs } \\
\text { Success depends on employees } \\
\text { The need for continuous learning } \\
\text { Delegation of authority }\end{array}$ & $\begin{array}{l}8,4412 \\
8,0294 \\
7,9412 \\
7,7941 \\
7,1373 \\
6,3725 \\
5,9412 \\
5,7647 \\
5,6863 \\
5,5294 \\
5,0196 \\
4,6176 \\
\end{array}$ & $\begin{array}{l}, 35702 \\
, 29275 \\
, 30931 \\
, 27316 \\
, 34386 \\
, 33263 \\
, 35299 \\
, 24019 \\
, 34412 \\
, 32846 \\
, 37021 \\
, 25580 \\
\end{array}$ & $\begin{array}{l}3,60575 \\
2,95664 \\
3,12392 \\
2,75874 \\
3,47278 \\
3,35940 \\
3,56502 \\
2,42584 \\
3,47546 \\
3,31724 \\
3,73896 \\
2,58344 \\
\end{array}$ \\
\hline $\begin{array}{l}\text { Features to Become a Successful Entrepreneur } \\
\text { Having an entrepreneurial spirit } \\
\text { Trust yourself } \\
\text { Building good relationships with people } \\
\text { Risk taking tendency } \\
\text { Evaluating opportunities } \\
\text { Success requirement } \\
\text { To be innovative } \\
\text { Creativity } \\
\text { To be decisive } \\
\text { The need for independence } \\
\text { Control focus }\end{array}$ & $\begin{array}{l}9,0882 \\
7,8725 \\
7,4118 \\
6,7549 \\
5,8529 \\
5,8039 \\
5,4020 \\
5,3137 \\
4,7843 \\
4,1863 \\
3,6176 \\
\end{array}$ & $\begin{array}{l}, 28113 \\
, 22966 \\
, 29830 \\
, 31633 \\
, 24979 \\
, 28624 \\
, 27596 \\
, 25729 \\
, 29214 \\
, 27542 \\
, 23317 \\
\end{array}$ & $\begin{array}{l}2,83927 \\
2,31940 \\
3,01269 \\
3,19479 \\
2,52276 \\
2,89088 \\
2,78703 \\
2,59848 \\
2,95051 \\
2,78159 \\
2,35487\end{array}$ \\
\hline $\begin{array}{l}\text { Factors Affecting Entrepreneurial Personality } \\
\text { Experience } \\
\text { Education } \\
\text { Culture } \\
\text { Family } \\
\text { Age } \\
\text { Gender } \\
\text { Marital Status }\end{array}$ & $\begin{array}{l}5,7843 \\
5,0294 \\
4,2255 \\
4,1667 \\
3,2647 \\
2,8627 \\
2,6569\end{array}$ & $\begin{array}{l}, 15492 \\
, 14376 \\
, 18998 \\
, 15830 \\
, 16599 \\
, 17237 \\
, 18667\end{array}$ & $\begin{array}{l}1,56463 \\
1,45191 \\
1,91868 \\
1,59878 \\
1,67643 \\
1,74083 \\
1,88530\end{array}$ \\
\hline
\end{tabular}

Participants gave the advantages of being an entrepreneur 6 points to the factor with the highest importance and 1 point to the factor with the lowest importance. The most important advantage of being an entrepreneur $(\bar{X}=4.7451)$ is the sense of achievement. Financial control $(\bar{X}=4.1275)$ and respect $(\bar{X}=3.4510)$ are seen as other important advantages of entrepreneurship. It is considered as social benefit with the lowest importance $(\bar{X}=2.6863)$ among the advantages of entrepreneurship. According to the findings, while entrepreneurship provides satisfaction with the sense of achievement in individuals, it also improves the ability to control financial assets. Şahin (2009) concluded in his study that the advantages of entrepreneurship compared to women entrepreneurs are the sense of achievement, being busy with a job, and financial freedom.

Participants gave 12 points to the factor they saw as the biggest disadvantage in being an entrepreneur, and 1 point to the factor they saw as the lowest disadvantage. The biggest disadvantage of being an entrepreneur is the burden of responsibility $(\bar{X}=8.4412)$. Income irregularity $(\bar{X}=8.0294)$, constantly dealing with financial problems $(\bar{X}=7.9412)$, taking risks $(\bar{X}=7.7941)$ and making personal sacrifices $(\bar{X}=7.1373)$ are considered as other important disadvantages. Dependence of success on employees $(\bar{X}=5.5294)$, the need for continuous learning $(\bar{X}=5.0196)$ and delegation of authority $(\bar{X}=4.6176)$ were evaluated as the disadvantages with the lowest low impact. According to the findings, it is possible to say that although entrepreneurs undertake all kinds of responsibilities and risks, they consider irregular income and loss as the disadvantages of entrepreneurship and as factors that negatively affect entrepreneurship. 
Participants gave 11 points to the factor that they considered the most important among the characteristics that one should have in order to become a successful entrepreneur, and 1 point to the factor that they considered the least important. The most important feature to be an entrepreneur is to have an entrepreneurial spirit $(\bar{X}=9.0882)$. Self-confidence $(\bar{X}=7.8725)$, establishing good relations with people $(\bar{X}=7.4118)$, risk taking tendency $(\bar{X}=6.7549)$ and seizing opportunities $(\bar{X}=5.8529)$ to be other entrepreneurs considered as important features. Participants; considers innovativeness $(\bar{X}=4.7843)$, creativity $(\bar{X}=4.6813)$ and decision-making ability $\overline{(X}=3.6176)$ as features that are of lower importance in order to be an entrepreneur. According to the findings; having an entrepreneurial spirit is considered the most important feature to be an entrepreneur. In this context, it is possible to say that the concept of entrepreneurship is correctly understood by those who participated in the research. On the other hand, the fact that very important features such as innovation, creativity and decision-making that ensure success and development are in the lower order of importance can be explained by the low entrepreneurship profile of the participants. Çetinkaya Bozkurt, Kalkan, Koyuncu, and Alparslan (2012) concluded that the characteristics required to be successful should be self-confidence, honesty and commercial ethics, and a tendency to take risks, respectively.

Participants gave 7 points to the factor with the highest importance and 1 point to the factor with the lowest importance among the factors that are effective in the formation of entrepreneurial personality. Work experience $(\bar{X}=5.7843)$ is considered to be the most important factor in the formation of an entrepreneurial personality. Education $(\bar{X}=5.0294)$ is the factor with secondary importance, while culture $(\bar{X}=4.2255)$ is the factor with third level importance. The least important factor in the formation of the entrepreneurial personality $(\bar{X}=2.6569)$ was evaluated as the marital status of the people. According to the findings, it can be said that demographic characteristics such as age, gender and marital status have a low effect on the formation of individuals' entrepreneurial personality, while personal development factors such as work experience, education and culture are highly effective. Chen and Lai (2010) determined that family, society, education and economic environment are effective factors in the formation of entrepreneurial personality.

\section{CONCLUSION}

According to the analysis of the data obtained from the study conducted in the TRA 2 Region, the sample group of the study is predominantly male, married, middle-aged, and has a low education level. The fact that the entrepreneur profile is male-dominated is in harmony with the general entrepreneurial profile of Turkey. It has been determined that the capital accumulation needed for entrepreneurship in the region is mainly met from the personal or family savings of individuals and the most important obstacle to entrepreneurship is the problem of financing. It is possible to say that people are willing to become entrepreneurs if the financing problem is overcome. The fact that the participants see and evaluate the opportunities as the most important stage in the entrepreneurship and business establishment process shows that they have an entrepreneurial spirit. The fact that having an entrepreneurial spirit is perceived as the most important and basic condition for being an entrepreneur also confirms this situation. Although entrepreneurs undertake all kinds of responsibilities and risks, they see irregular income and risk of loss as disadvantages of entrepreneurship. Therefore, these factors, which are seen as a disadvantage for entrepreneurs, negatively affect the entrepreneurship profile of the region and prevent the increase in the number of new entrepreneurs.

It has been concluded that the effect of demographic characteristics such as age, gender and marital status on the formation of the entrepreneurial personality of individuals in the TRA2 region is low; personal development factors such as work experience, education, and culture have a high effect. In addition, it is possible to say that while entrepreneurship provides the satisfaction of the sense of achievement in individuals, it also improves the ability to control financial assets. Çetinoğlu and Büber (2012) concluded that 358 entrepreneurs operating in OSTIM Organized Industrial Zone have high self-control and leadership characteristics. Sönmez and Toksoy (2014) concluded that entrepreneurs plan to solve their capital needs with KOSGEB supports as well as equities, family assistance and bank loans. Tan (2015) concluded that the most successful entrepreneur candidates among 400 people who participated in KOSGEB Entrepreneurship Trainings were male participants between the ages of 25-34 with a university or higher education level. Gül and Gül (2018) determined that the most important entrepreneurial characteristics of 60 women entrepreneurs receiving KOSGEB support are self-confidence, success and economic independence. Kartal (2018) concluded that there is a positive relationship between the personality traits of university students and their entrepreneurial tendencies. The data obtained from the study are similar to the literature.

The TRA2 region has limited opportunities for private and public investments. It is seen that KOSGEB supports are especially important for entrepreneur candidates who are insufficient in terms of capital in the region where production is low and the employment rate is low. In this context, it is important to develop support for entrepreneurs, to provide long-term capital support to entrepreneurial candidates under favorable 
conditions, to provide more limited support to businesses that will operate in the manufacturing sector, and to encourage entrepreneurs for joint investment and institutionalization. In addition, the expansion of large-scale corporate enterprises with a stronger capital structure instead of small enterprises will contribute more to the regional economy. In addition to the factors that lead individuals to become entrepreneurs, it is important to determine the problems that entrepreneurs face while establishing a business and carrying out their activities. In similar studies, the change in the process of entrepreneurship according to demographic variables can be examined. In addition, the evaluation of the results of the findings to be obtained by expanding the research population and the number of samples will contribute to the literature.

\section{REFERENCES}

Acs, Z. J.; Desai, S. and Hessels, J. (2008). Entrepreneurship, Economic Development and Institutions. Small Business Economics, 0(31), 219-234.

Acs, Z. J. and Szerb, L. (2010). The Global Entrepreneurship and Development Index (GEDI). Opening Up Innovation: Strategy, Organization and Technology. London: Imperial College.

Alvarez, C.; Urbano, D. and Amaros, J. E. (2014).GEM Research:Achievements and Challenges. Small Business Economics, 0(42), 445-465.

Arıkan, S. (2004). Girişimcilik Temel Kavramlar ve Bazı Güncel Konular. Ankara. Siyasal Kitabevi.

Audretsch, D. B. (2004).Sustaining Innovation and Growth: Public Policy Support for Entrepreneurship. Industry and Innovation, 11(3), 167-191.

Autio, E. (2016). Entrepreneurship Support in Europe: Trends and Challenges for EU Policy. (Ed. Policy Reports). In Report Prepared for EU DG Growth. Brussels: European Commission.

Bygrave, W. (2003). The Entrepreneurial Process. (Eds. W. Bygrave and A. Zacharakis). The Portable MBA in Entrepreneurship, (3rd ed.). New York: John Wiley and Sons.

Caliendo, M.; Fossen, F. and Kritikos, A. S. (2014). Personality Characteristics And The Decisions To Become and Stay Self-Employed. Small Business Economics, 0(42), 787-814.

Chen, Y.F. and Lai, M.C. (2010). Factors Influencing the Entrepreneurial Attitude of Taiwanese Tertiary-Level Business Students. Social Behavior and Personality, 38(1), 1-12.

Çetinkaya Bozkurt, Ö.; Kalkan, A.; Koyuncu, O. and Alparslan, A. M. (2012). Türkiye'de Girişimciliğin Gelişimi: Girişimciler Üzerinde Nitel Bir Araştırma. Süleyman Demirel Üniversitesi Sosyal Bilimler Enstitüsü Dergisi, 1(15), 229-247.

Çetinoğlu, T. and Büber, R. (2012). Ostim Organize Sanayi Bölgesinde Girişimcilik Açısından Kültür Ve Kişilik Özelliklerinin Analizine Yönelik Bir Alan Araştırması. Dumlupınar Üniversitesi Sosyal Bilimler Dergisi, 0(33), 193-210.

Dahlstrand, A. L. and Stevenson, L. (2010). Innovative Entrepreneurship Policy: Linking Innovation and Entrepreneurship In A European Context. Annals of Innovation \& Entrepreneurship, 5602, 1(1), 1-15.

Díez-Martín, F.; Blanco-González, A. and Prado-Román, C. (2016). Explaining Nation-Wide Differences in Entrepreneurial Activity: A Legitimacy Perspective. International Entrepreneurship and Management Journal, 0(12), 1079-1102.

Filion, L. J. (1998). Two Types of Entrepreneurs: The Operator and the Visionary: Consequences for Education. Montréal: École Des Hautes Études Commerciales, Working Paper, 11.

Gartner, W. B. (1989). Who is an Entrepreneur? Is the Wrong Question?. American Journal of Small Business, 12(4), 47-67.

GEM (Global Entrepreneurship Monitor) (2020). 2019/2020 Global Report. London: Bobson.

Gustafsson, A.; Tingvall, P. G. and Halvarsson, D. (2020). Subsidy Entrepreneurs: An inquiry into Firms Seeking Public Grants. Journal of Industry, Competition and Trade, 20(3), 439-478.

Gül, M. and Gül, K. (2018). Balıkesir İlinde Kadın Girişimci Profili ve Sorunları: Yiyecek Sektöründe Bir Uygulama. Dumlupınar Üniversitesi Sosyal Bilimler Dergisi, 0(56), 82-96.

Hisrich, R.; Langan-Fox, J. and Grant, S. (2007). Entrepreneurship Research and Practice: A Call To Action for Psychology. American Psychologist, 0(62), 575-589.

Kartal, Ö. (2018). Kişilik Özelliklerinin Girişimcilik Eğilimi ile İlişkisi: Kastamonu Üniversitesi İIBF Örneği. The International New Issues in Social Sciences, 6(1), 39-53.

KOSGEB (2019a). 2018 Yll Faaliyet Raporu. Ankara.

KOSGEB (2019b). 2019 Yılı Performans Programı. Ankara.

KOSGEB (2019c). Girişimcilik Destek Programı Uygulama Esasları. (UE-05/2019). https://www.kosgeb.gov.tr/site/tr/genel/destekdetay/1231/girisimcilik-destek-programi $\quad$ adresinden 20.03.2021 tarihinde erişildi.

KOSGEB (2020a). 2019 Yllı Faaliyet Raporu. Ankara.

KOSGEB (2020b). Yeni Girişimci Desteği Nihai Değerlendirme Raporu. Ankara.

KOSGEB (2021a). 2020 Yll Faaliyet Raporu. Ankara. 
KOSGEB Girișimcilik Destekleri (2021b). https://www.kosgeb.gov.tr/ adresinden 25.03.2021 tarihinde erișildi. Kozubíková, L.; Dvorský, J.; Cepel, M. and Balcerzak, A. P. (2017). Important Characteristics Of An Entrepreneur In Relation To Risk Taking: Czech Republic Case Study. Journal of International Studies, 10(3), 220-233.

Küçük ve Orta Büyüklükteki İşletmelerin Tanımı, Nitelikleri ve Sınıflandırılması Hakkında Yönetmelik $\begin{array}{llllll}\text { (18.11.2005). T.C. } & \text { Resmi } & \text { Gazete, } & \text { 25997, } & \text { 44(5) } & \text { 0-0. }\end{array}$ https://www.mevzuat.gov.tr/MevzuatMetin/3.5.20059617.pdf adresinden 25.03.2021 tarihinde erişildi.

Kritikos, A. S. (2014). Entrepreneurs and Their Impact on Jobs and Economic Growth. IZA World of Labor, $0(8), 1-10$.

Man, T. W.; Lau, T. and Chan, K. F. (2002). The Competitiveness of Small And Medium Enterprises: A Conceptualization With Focus on Entrepreneurial Competencies. Journal of Business Venturing, 17(2), 123-142.

Man, T. W.; Lau, T. and Snape, E. (2008). Entrepreneurial Competencies and The Performance of Small and Medium Enterprises: An Investigation Through A Framework of Competitiveness. Journal of Small Business \& Entrepreneurship, 21(3), 257-276.

Maritz, A. and Donovan, J. D.(2015).Entrepreneurship And Innovation. Education and Training, 57(1), 74-87.

Meyer, N. and De Jongh, J. (2018). The Importance of Entrepreneurship as a Contributing Factor to Economic Growth and Development: The Case of Selected European Countries. Journal of Economics and Behavioral Studies, 10(4), 287-299.

Mittelstädt, A. and Cerri, F. (2008). Fostering Entrepreneurship For Innovation. OECD Science, Technology and Industry Working Papers, 2008(05), 4-128.

Müftüoğlu, T. and Durukan, T. (2004), Girişimcilik ve KOBİler. Ankara: Gazi Kitabevi.

Nishantha, B.( 2009) Influence of Personality Traits and Socio-Demographic Background of Undergraduate Students on Motivation for Entrepreneurial Career: The Case of Sri Lanka. Ryukoku Univ. Dep. Bull. Pap, 49(2), 71-82.

Ortega-Argile's, R. and Voigt, P. (2009). Business $R \& D$ in SMEs. Sevilla/Spain: IPTS Working Paper on Corporate R\&D and Innovation, No. 07/ 2009.

Raab, G.; Stedham, Y. and Neuner, R.M. (2005). Entrepreneurial Potential: An Exploratory Study of Business Students in The U.S. and Germany. Journal of Business and Management, 11(2), 71-88.

Şahin, E. (2009). Kadın Girişimcilik ve Konya İlinde Kadın Girişimcilik Profili Üzerine Bir Uygulama. Sosyal ve Ekonomik Araştırmalar Dergisi, 11(17), 287- 309.

Sencer, M. (1989). Toplum Bilimlerinde Yöntem. İstanbul: Beta Basım.

Serhat Kalkınma Ajansı (2013). TRA2 Bölgesi (Ăgrı, Ardahan, I ğdır ve Kars) 2014 - 2023 Bölge Planı. Kars.

Sevinç, A. and Eren, T. (2019).KOBİ'ler İçin KOSGEB Destek Modellerinin Çok Ölçütlü Karar Verme Yöntemleri İle Sıralanması. Uluslararası Mühendislik Araştırma ve Geliştirme Dergisi, 11(1), 409425.

Solesvik, M. (2012).Entrepreneurial Competencies In Emerging Economy Context. In 17th Nordic Conference on Small Business Research (p. 1-17). Helsinki.

Sönmez, A. and Toksoy, A .(2014). Türkiye'de Girişimcilik ve Türk Girişimci Profili Üzerine Bir Analiz. Yönetim ve Ekonomi: Celal Bayar Üniversitesi İktisadi ve İdari Bilimler Fakültesi Dergisi 21(2), 41-58.

Spulber, D. F. (2008). The Economic Role of the Entrepreneur, Northwestern University. http://lawlab.org/EconomicRoleoftheEntrepreneur.pdf adresinden 25.03.2021 tarihinde erişildi.

Stevenson, H. and Jarillo, J. (1990). A Paradigm of Entrepreneurship: Entrepreneurial Management. Strategic Management Journal, 0(11), 17-27.

Tan, F. Z. (2015). KOSGEB Uygulamalı Girişimcilik Eğitimi Adayları Üzerine Kastamonu İlinde Bir Araştırma. Business \& Management Studies: An International Journal, 3(3), 382-417.

Toma, S.G.; Grigore, A. M. and Marinescu, P. (2014). Economic Development and Entrepreneurship. Procedia Economics and Finance, 0(8),436-443.

United Nations, Department of Economic and Social Affairs, Statistics Division (2018). Technical Report on Measuring Entrepreneurship: Lessons Learned from the EDGE Project. New York.

Ürper, Y. (2013). Girişimcilik. Eskişehir: T.C. Anadolu Üniversitesi, Yayını No: 3002.

Wennekers, S. and Thurik, R. (1999). Linking Entrepreneurship and Economic Growth. Small Business Economics, 13(1), 27-55.

Zhao, F. (2005). Exploring the Synergy Between Entrepreneurship And Innovation. International Journal of Entrepreneurial Behavior \& Research, 11(1), 25-41.

https://www.kosgeb.gov.tr/site/tr/genel/destekdetay/1231/girisimcilik-destek-programi adresinden 25.03.2021 tarihinde erişildi.

www.kosgeb.gov.tr adresinden 24.03.2021 tarihinde erişildi. 